Психолого-педагогічні проблеми становлення сучасного фахівця Випуск 2018 УДК 616.132.2-004.6-07:611.018.74-092-036:616.127-0052.8-036.11-089.843 DOI 10.26697/9786177089017.2018.77

(C) Мінухіна Д. В., Бабаджан В. Д., Бойко В. В., 2018, Мінухін В. В., Мінухін Д. В., Свтушенко Д. О., 2018 Мінухіна Діана Валеріїна

Харківський національний медичний університет

Бабаджан Володимир Данилович

Харківський національний медичний університет

Бойко Валерій Володимирович

Державна установа «Інститут загальної та невідкладної хірургії

ім. В. Т. Зайцева Національної академії наук України»,

Харківський національний медичний університет

Мінухін Валерій Володимирович

Харківський національний медичний університет

Мінухін Дмитро Валерійович

Харківський національний медичний університет

Свтушенко Денис Олександрович

Харківський національний медичний університет

\title{
РОЛЬ МАРКЕРІВ ЕНДОТЕЛІАЛЬНОЇ ДИСФУНКЦІЇ У ДІАГНОСТИЦІ СТУПЕНЮ АТЕРОСКЛЕРОТИЧНОГО УРАЖЕННЯ КОРОНАРНИХ СУДИН У ХВОРИХ НА ГОСТРИЙ ІНФАРКТ МІОКАРДА 3 КОРОНАРНИМ СТЕНТУВАННЯМ
}

Проведена оцінка рівня інгібітора активатора плазміногену 1 типу та асиметричного діметіларгінину у хворих на гострий інфаркт міокарда в залежності від наявності або відсутності иукрового діабету 2 типу та характеру ураження коронарних артерій, а також ïx прогностичне значення у ступені розвитку атеросклеротичного ураження коронарних судин. У хворих на гострий інфаркт міокарда незалежно від наявності або відсутності иукрового діабету 2 типу визначається підвищення рівнів ІАП-1 та АДМА у порівнянні з контрольною групою $(p<0,05)$. У хворих з гемодинамічно значущими стенозами коронарних артерій ( $\geq 70 \%)$ визначено підвищення рівню ІАП-1 та АДМА при наявності, так $i$ відсутності ЦД 2 типу $(p<0,05)$. У хворих на ГІМ з дифузним ураженням коронарних артерій 3 супутнім ЦД 2 типу, так $i$ без такого рівень ІАП-1 та АДМА достовірно вище, ніж у хворих без дифузного ураження коронарных судин $(p<0,05)$. При порівнянні площі під ROC-кривими більшою діагностичною иінністю для прогнозування дифузного ураження коронарних судин у хворих на ГІМ з супутнім ЦД 2 типу володіє ІАП-1 y порівнянні з АДМА. Визначення рівнів ІАП-1 та АДМА має велике значення як у прогнозуванні гемодинамічно значущих стенозів 
коронарних артерій, так $i$ в діагностиці дифузного ураження коронарного русла, що сприяє профілактиці розвитку ускладнень ГІМ. Ключові слова: інгібітор активатора плазміногену 1 типу, асиметричний діметіларгінін, гострий інфаркт міокарда, стеноз коронарних артерій, иукровий діабет 2 типу.

Вступ. Гострий інфаркт міокарда (ГІМ) продовжує посідати одне 3 провідних місць серед причин смертності населення. 3 високим ризиком серцево-судинних ускладнень асоціюються також деякі показники ендотеліальної дисфункції, яким належить ключова роль у патогенезі розвитку серцево-судинних ускладнень, що обумовлює актуальність вивчення взаємозв'язку маркерів дисфункції ендотелію 3 розвитком і прогресуванням атеросклеротичного ураження судин, в тому числі і у хворих на цукровий діабет 2 типу (ЦД 2 типу), для яких характерно прискорений розвиток атеросклерозу [1].

Одним 3 найнебезпечніших факторів ризику розвитку ГІМ $є$ цукровий діабет, що може ускладнювати його перебіг [2]. Дисфункція ендотеліальної судинорозширювальної системи, яка супроводжується зниженням рівнів оксид азоту (NO), є характерною рисою пацієнтів, котрі знаходяться під загрозою захворювання коронарних артерій, тому коронарна вазодилататорна дисфункція може передбачати тривале прогресування атеросклерозу та частоту серцево-судинних подій $[3 ; 4]$.

Ендотелій, що покриває судинну стінку, відомий як ключовий регулятор судинного гомеостазу. У нормі судинної фізіології NO відіграє вирішальну роль у підтримці судинної стінки у стані виникнення через його прямий вазодилятуючий ефект, гальмування запалення, проліферації клітин та тромбозу [5]. Субстратом для синтезу NO під дією ендотеліальної синтази оксиду азота виступає амінокислота L-аргінін - основна ендогенна амінокислота. В організмі L-аргінін, як і інші амінокислоти, піддається різним метаболічним змінам. Зокрема, на L-аргінінові залишки, що входять до складу різних білків, як в ендотелії, так і в інших тканинах, під дією ферментів переносяться метильні групи і утворюють метильовані амінокислоти, в тому числі асиметричний діметіларгінін (АДМА), який може приводити до розвитку ендотеліальної дисфункції [6]. Нещодавно проведений метааналіз С. Хuan продемонстрував, що підвищення рівня АДМА супроводжується підвищеним ризиком коронарної хвороби серця [7]. Високий ризик судинних катастроф є спонукальним мотивом вивчення патогенетичних механізмів тромбоутворення при ЦД 2 типу. Інгібітор активатора плазміногену 1 типу (ІАП-1) є членом суперродини інгібіторів серинових протеаз і основного інгібітору фібринолізу в системі активатора плазміногену [8]. Висока 
Психолого-педагогічні проблеми становлення сучасного фахівця Випуск 2018

концентрація ІАП-1 відіграє ключову роль в патогенезі артеріального i венозного тромбозу i, отже, сприяє виникненню тромботичних подій [9]. Тому в останні роки значну увагу дослідників привертає роль зазначених маркерів у розвитку серцево-судинних захворювань. Однак, діагностична роль ІАП-1 та АДМА у прогресуванні ураження судин у пацієнтів з ГІМ як з ЦД 2 типу, так і без такого, вивчена недостатньо.

Мета дослідження - оцінити рівні інгібітора активатора плазміногену 1 типу та асиметричного діметіларгінину у хворих на гострий інфаркт міокарда в залежності від наявності або відсутності цукрового діабету 2 типу та характеру ураження коронарних артерій, а також їх прогностичне значення у ступені розвитку атеросклеротичного ураження коронарних судин.

Матеріали і методи дослідження. Було обстежено 130 хворих, які перебували на лікуванні у кардіологічному відділенні КЗОЗ «Обласна клінічна лікарня - Центр екстреної медичної допомоги та медицини катастроф» м. Харкова, серед яких 44 жінки $(33,85 \%)$ та 86 чоловіків (66,15\%). Усіх пацієнтів було поділено на групи: основна 73 хворих на ГІМ із супровідним ЦД 2 типу (серед них - 43 чоловік, 30 жінок, середній вік хворих $62,73 \pm 1,39$ років); порівняльна - 57 хворих на ГІМ з відсутністю ЦД 2 типу (43 чоловіки і 14 жінок, середній вік $63,98 \pm 1,47$ років); контрольна група - 20 практично здорових осіб (серед них 10 чоловіків і 10 жінок, 60,85 $\pm 1,37$ років).

Усі хворі 1-ї та 2-ї груп були розподілені на підгрупи в залежності наявності або відсутності гемодинамічно значущих стенозів коронарних артерій. При оцінці гемодинамічної значущості ураження коронарного русла ми орієнтувалися на анатомічну класифікацію ураження КА, згідно з якою гемодинамічно значущими прийнято вважати стенози КА понад 70\%, а гемодинамічно незначними - менше 70\% [10].

Хворі 1-ї групи розподілені на підгрупи: зі стенозом КА $<70 \%$ $(\mathrm{n}=28)$ та стенозом $\geq 70 \%(\mathrm{n}=45)$, а пацієнти 2-ї групи - на підгрупи 24 та 33 хворих відповідно. Також в залежності від наявності дифузного (полісегментарного) ураження коронарних судин хворі обох груп були розподілені на підгрупи: 1-а група - 3 дифузним ураженням КА (n=23) та без такого $(\mathrm{n}=53)$; 2-a група - на підгрупи 6 та 51 пацієнтів відповідно. Діагноз ГІМ було встановлено згідно 3 Наказом Міністерства охорони здоров’я України № 455 від 02.07.2014 p. «Уніфікований клінічний протокол екстреної, первинної, вторинної (спеціалізованої) та третинної (високоспеціалізованої) медичної допомоги та медичної реабілітації хворих на гострий коронарний синдром 3 елевацією сегмента ST, базуючись на клінічних, електрокардіографічних та біохімічних критеріях» [11]. 


\section{Збірник наукових статей}

Тривалість ЦД 2 типу у хворих з ГІМ - від одного до 30 років. Діагноз ЦД 2 типу визначали відповідно до спільних рекомендацій Американської діабетичної асоціації (ADA - American Diabetes Association) та Європейської асоціації 3 вивчення ЦД (EASD European Association for the Study of Diabetes).

Критеріями виключення $є$ ревматологічні, онкологічні хвороби, дифузні захворювання сполучної тканини, захворювання гіпофіза та гіпоталамуса, захворювання щитоподібної залози, наявність симптоматичних гіпертензій. Усім хворим проводили коронарографію вінцевих судин серця у стандартних проекціях за допомогою ангіографа Siemens Axiom Artis. Вміст АДМА був встановлений імуноферментним методом, використовуючи комерційну систему тестування Immunodiagnostik компанії ADMA Xpress ELISA Kit (Австрія). Вміст ІАП-1 визначали імуноферментним методом 3 використанням комерційної тест-системи виробництва фірми Technoclone PAI-1 ELISA Kit (Австрія).

Результати. У хворих на гострий інфаркт міокарда як за наявністю, так і відсутністю супутнього цукрового діабету 2 типу, виявлено підвищення рівнів ІАП-1 та АДМА у порівнянні 3 контрольною групою $(\mathrm{p}<0,05)$.

Крім того, у пацієнтів 1-ї групи у порівнянні з 2-ю групою статистично значимо підвищувалися рівні IAП-1 $(62,59 \pm 1,50$ та $52,09 \pm 1,63$ нг/мл) та АДМА $(1,21 \pm 0,04$ та $0,49 \pm 0,02$ мкмоль/л) відповідно ( $\mathrm{p}<0,05)$.

При наявності стенозу коронарних судин більше $70 \%$ виявлено підвищення рівнів АДМА на 58,9\% у пацієнтів 1-ї групи у порівнянні 3 хворими 2-ї групи $(1,41 \pm 0,05$ та $0,58 \pm 0,03$ мкмоль/л відповідно $(\mathrm{p}<0,05))$. У разі дифузного ураження коронарних артерій рівень АДМА у хворих з супутнім цукровим діабетом 2 типу перевищував такий у пацієнтів без діабету на $55,2 \%(1,54 \pm 0,35$ та $0,69 \pm 0,07$ мкмоль/л відповідно) ( $<0,05)$. Щодо вмісту ІАП-1 у сироватці крові хворих зі стенозами КА $\geq 70 \%$ визначалося підвищення цього маркеру у хворих з супутнім ЦД 2 типу на $15,1 \%$ у порівнянні з пацієнтами без

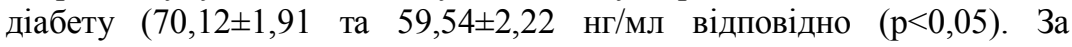
наявності дифузного ураження КА рівень ІАП-1 склав $70,67 \pm 2,68$

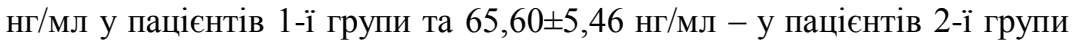
$(\mathrm{p}<0,05)$.

При оцінці предикторних властивостей маркерів IAП-1 та АДМА у прогнозуванні гемодиномічно значущих стенозів КА за допомогою ROC-анализу продемонстровано щодо стенозу КА $\geq 70 \%$ чутливість та специфічність моделі высокі та складають 78,57 та $100 \%$

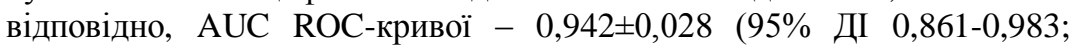
$\mathrm{p}<0,0001)$; щодо ІАП-1 - чутливість та специфічність метода 
Психолого-педагогічні проблеми становлення сучасного фахівця Випуск 2018 складають 100 та 100\% відповідно, AUC ROC-кривої -1,000 (95\% ДI 0,951-1,000; $\mathrm{p}<0,0001)$.

При порівнянні AUC ROC-кривих IAП-1 та АДМА для прогнозування гемодинамічно значущих стенозів КА встановлено статистично значима різниця між AUC ROC-кривих IAП-1 та АДМА: різниця між площами ROC-кривих склала 0,058 $\pm 0,028$ (p<0,0001).

Також нами була оцінена предикторна роль рівнів IAП-1 та АДМА для прогнозування дифузного ураження КА (рисунок 4).

Визначено, що предикторна цінність рівню АДМА для прогнозування дифузного ураження КА вище, ніж ІАП-1: чутливість и специфічність метода склали 90 и 91,3\% відповідно, AUC ROC-кривої

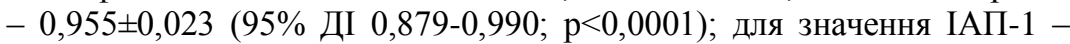
чутливість и специфічність метода склали 67,31 та $100 \%$ відповідно,

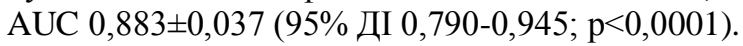

При порівнянні AUC ROC-кривих IAП-1 та АДМА для прогнозування наявності дифузного ураження КА була виявлена статистично значима різниця: різниця між AUC ROC-кривих IAП-1 та АДМА склала $0,072 \pm 0,014(\mathrm{p}<0,001)$.

Результати та їх обговорення. Наші дані свідчать про підвищення маркерів ендотеліальної дисфункції, а саме, інгібітора активатора плазміногену 1 типу та асиметричного діметіларгініну у сироватці крові у пацієнтів на гострий інфаркт міокарда з супутнім цукровим діабетом 2 типу та про їх високу предикторну властивість щодо діагностики наявності та ступеня вираженості стенотичного ураження коронарних артерії. Отримані результати підтверджують вплив ендотеліальної дисфункції та маркерів тромбоутворення на розвиток і прогресування атеросклеротичного стенозу вінцевих судин, особливо вираженого на фоні супутнього цукрового діабету 2 типу.

При порівнянні AUC ROC-кривих IAП-1 та АДМА для прогнозування наявності гемодинамічно значущих стенозів коронарних судин встановлена більша предикторна цінність IАП-1, проте для прогнозування наявності дифузного ураження коронарних судин більшою діагностичною цінністю володів АДМА.

Визначення рівнів ІАП-1 та АДМА у сироватці крові хворих на ГІМ має велике значення, як у прогнозуванні гемодинамічно значущих стенозів коронарних артерій, так і у разі їх дифузного ураження, що необхідно враховувати при проведенні діагностики та лікування ГІМ та прогнозуванні ймовірних несприятливих серцево-судинних подій.

Висновки. Стенотичне ураження коронарних судин $\geq 70 \%$ визначалося у 61,64\% хворих $(n=45)$ на гострий інфаркт міокарда 3 супутнім цукровим діабетом 2 типу та у 57,89\% (n=33) хворих без ЦД 2 типу. 


\section{Збірник наукових статей}

У хворих на гострий інфаркт міокарда 3 супутнім цукровим діабетом 2 типу у порівнянні 3 хворими без цукрового діабету при наявності гемодинамічно значущих стенозів коронарних артерій визначено підвищення рівнів ІАП-1 на $15,09 \% \quad(70,12 \pm 1,91$ та $59,54 \pm 2,22$ нг/мл відповідно) та АДМА на $58,87 \%(1,41 \pm 0,05$ та $0,58 \pm 0,03$ мкмоль/л відповідно) $(\mathrm{p}<0,05)$.

Наявність гемодинамічно значущих стенозів коронарних артерій у пацієнтів на гострий інфаркт міокарда, як 3 супутнім цукровим діабетом 2 типу, так і без такого, асоціюється більшою мірою 3 підвищенням ІАП-1, ніж АДМА (чутливість прогностичної моделі $100 \%$ та 78,57\% відповідно), що вказує на визначну роль цього маркеру у розвитку атеросклеротичного ураження та тромбоутворення коронарних судин.

При побудові моделі прогнозу дифузного ураження коронарних судин більш точнішою предикторною властивістю володіє асиметричний діметіларгінін (AUC $=0,955, Д \mathrm{I}=0,879-0,990)$, у той час, як інгібітор активатора плазміногену 1 типу мав меншу, але теж досить високу предикторну якість моделі (AUC=0,883, ДI=0,790-0,945), що свідчить про його роль у патогенезі розвитку ендотеліальної дисфункції $(\mathrm{p}<0,001)$.

Визначення рівнів ІАП-1 та АДМА має велике значення як у прогнозуванні атеросклеротичного ураження коронарних судин, так і в діагностиці гемодинамічно значущих стенозів коронарних артерій та дифузного ураження коронарного русла, що сприяє покращенню діагностики та профілактиці розвитку ускладнень ГІМ.

\section{Література}

1. Matsuzawa Y, Lerman A. Endothelial dysfunction and coronary artery disease: assessment, prognosis, and treatment. Coron Artery Dis. 2014 Dec;25(8):713-24. doi:10.1097/MCA.0000000000000178. PubMed PMID: 25365643; PubMed Central. PMCID: PMC4220301.

2. Huang Y, Cai X, Mai W, Li M, Hu Y. Association between prediabetes and risk of cardiovascular disease and all cause mortality: systematic review and meta-analysis. BMJ. 2016 Nov 23;355:i5953. doi:10.1136/bmj.i5953. PubMed PMID: 27881363; PubMed Central PMCID: PMC5121106.

3. Bohlen HG. Nitric oxide and the cardiovascular system. Compr Physiol. 2015 Apr;5(2):808-23. doi:10.1002/cphy.c140052. PubMed PMID: 25880514.

4. Gaiz A, Mosawy S, Colson N, Singh I. Thrombotic and cardiovascular risks in type two diabetes; Role of platelet hyperactivity. 
doi:10.1016/j.biopha.2017.07.121. PubMed PMID: 28787703.

5. Dong Y, Wu Y, Choi HC, Wang S. Diabetic endothelium dysfunction, cardiovascular complications, and therapeutics. J Diabetes Res. 2016;2016:5349801. doi:10.1155/2016/5349801. PMID: 26989698; PMCID: PMC4775813.

6. Franceschelli S, Ferrone A, Pesce M, Riccioni G, Speranza L. Biological functional relevance of asymmetric dimethylarginine (ADMA) in cardiovascular disease. Int $\mathrm{J}$ Mol Sci. 2013 Dec 16;14(12):24412-21. doi:10.3390/ijms141224412. PubMed PMID: 24351825; PubMed Central PMCID: PMC3876119.

7. Xuan C, Tian QW, Li H, Zhang BB, He GW, Lun LM. Levels of asymmetric dimethylarginine (ADMA), an endogenous nitric oxide synthase inhibitor, and risk of coronary artery disease: A meta-analysis based on 4713 participants. Eur J Prev Cardiol. 2016 Mar;23(5):502-10. doi:10.1177/2047487315586094. PubMed PMID: 25956428.

8. Fortenberry YM. Plasminogen activator inhibitor-1 inhibitors: a patent review (2006-present). Expert Opin Ther Pat. 2013 Jul;23(7):801-15. doi:10.1517/13543776.2013.782393. PubMed PMID: 23521527.

9. Song C, Burgess S, Eicher JD, O'Donnell CJ, Johnson AD. Causal Effect of Plasminogen Activator Inhibitor Type 1 on Coronary Heart Disease. J Am Heart Assoc. 2017 May; 6(6). pii: e004918. doi:10.1161/JAHA.116.004918.

10. Unified clinical protocol for primary and secondary (specialized) medical care: Stable ischemic heart disease [Internet]. Kyiv: Ministry of Healthcare of Ukraine; 2016 Mar 02 No. 152 [cited 2018 Mar 31]. Available from

http://mtd.dec.gov.ua/images/dodatki/2016_152_IHS/2016_152_YKPMD_I H.pdf. [in Ukrainian].

11. Unified clinical protocol of emergency, primary, secondary (specialized) and tertiary (highly specialized) medical care and medical rehabilitation of patients with acute coronary syndrome with elevation of segment ST [Internet]. Kyiv: Ministry of Healthcare of Ukraine; 2014 Jul 02 No. 455 [cited 2018 Mar 31]. Available from http://mtd.dec.gov.ua/images/dodatki/2014_455_GKS/2014_455nakaz_GK S.pdf. [in Ukrainian].

Диана Минухина, Владимир Бабаджан, Валерий Бойко, Валерий Минухин, Дмитрий Минухин, Денис Евтушенко. Прогностическая роль маркеров эндотелиальной дисфункции в диагностике степени атеросклеротического поражения коронарных сосудов у пациентов с острым инфарктом миокарда с коронарным стентированием. 


\section{Збірник наукових статей}

Для оченки уровней ингибитора активатора плазминогена типа 1 (IAP-1) и асимметричного диметиларгинина у пациентов с острым инфарктом миокарда в зависимости от наличия или отсутствия сахарного диабета 2-го типа и характера заболевания коронарной артерии, а также их прогностической ценности в степени развития атеросклеротических поражений коронарных сосудов. У пачиентов с острым инфарктом миокарда, независимо от наличия или отсутствия диабета типа 2, наблюдается увеличение уровней IAP-1 и ADMA по сравнению с контрольной группой $(p<0,05)$. У пациентов $c$ гемодинамически значимым стенозом коронарных артерий (70\%) определяли уровень IAP-1 и ADMA в присутствии и отсутствии диабета типа 2 (p<0,05). У пациентов $с$ ГИ $c$ диффузным заболеванием коронарной артерии со связанным типом DM 2 и без такого уровня IAP-1 и ADMA статистически достоверно выше, чем у пациентов без диффузной болезни коронарной артерии $(p<0,05)$. При сравнении площади под кривыми ROC с большим диагностическим значением для прогнозирования степени атеросклеротических поражений коронарных сосудов у пащиентов с GIM с сопутствующим диабетом типа 2 IAP-1 по сравнению с ADMA. Определение обоих уровней IAP-1 и АDMA важно для прогнозирования атеросклеротического повреждения коронарных сосудов $u$ диагностики гемодинамически значимого стеноза коронарной артерии и диффузного повреждения коронарного русла, что способствует предотвращению развития осложнений АМИ.

Ключевые слова: ингибитор активатора плазминогена типа 1, асимметричный диметиларгинин, острый инфаркт миокарда, атеросклероз коронарной артерии, сахарный диабет 2 типа.

\section{Diana Minukhina, Vladimir Babadzhan, Valeriy Boyko, Valeriy Minukhin, Dmitriy Minukhin, Denys Yevtushenko. Prognostic role of markers of endothelial dysfunction in the diagnosis of the degree of atherosclerotic lesion of coronary vessels in patients with acute myocardial infarction with coronary stenting.}

To evaluate the levels of type 1 plasminogen activator inhibitor (IAP-1) and asymmetric dimethylargrinine in patients with acute myocardial infarction, depending on the presence or absence of type 2 diabetes mellitus and the nature of coronary artery disease, as well as their prognostic value in the degree of development of atherosclerotic lesions of coronary vessels. In patients with acute myocardial infarction, regardless of the presence or absence of type 2 diabetes, an increase in levels of IAP-1 and ADMA in comparison with the control group $(p<0.05)$ is observed. In patients with hemodynamically significant stenosis of coronary arteries $(\geq 70 \%)$, the level of IAP-1 and ADMA in the presence and absence of type 2 diabetes 
Психолого-педагогічні проблеми становлення сучасного фахівця Випуск 2018 $(p<0,05)$ was determined. In patients with GI with diffuse coronary artery disease with associated DM 2 type, and without such a level of IAP-1 and ADMA is statistically significantly higher than in patients without diffuse coronary artery disease ( $p<0.05)$. When comparing the area under ROC curves with a greater diagnostic value for predicting the degree of atherosclerotic lesions of coronary vessels in patients with GIM with concomitant type 2 diabetes has IAP-1 in comparison with ADMA. Determination of both levels of IAP-1 and ADMA are important in predicting atherosclerotic damage of coronary vessels and in the diagnosis of hemodynamically significant coronary artery stenosis and diffuse damage of the coronary bed, which contributes to preventing the development of complications of AMI.

Keywords: plasminogen activator inhibitor type 1, asymmetric dimethylarginine, acute myocardial infarction, coronary artery atherosclerosis, type 2 diabetes mellitus.

Стаття надійшла до редакційної колегії 04.05.2018 Прийнято до друку 07.05.2018

\section{Інформація про авторів:}

Минухіна Діана Валеріївна - аспірант кафедри внутрішньої медицини № 2 та клінічної імунології та алергології, Харківський національний медичний університет.

Бабаджан Володимир Данилович - доктор медичних наук, доцент, професор кафедри внутрішньої медицини № 2 та клінічної імунології та алергології, Харківський національний медичний університет.

Бойко Валерій Володимирович - доктор медичних наук, професор, член-кореспондент НАМН України, Заслужений діяч науки і техніки України, директор, ДУ Інститут загальної та невідкладної хірургії ім. В. Т. Зайцева Національної академії медичних наук України; завідувач кафедри хірургії №1, Харківський національний медичний університет.

Мінухін Валерій Володимирович - доктор медичних наук, доцент, професор кафедри мікробіології, вірусології та імунології, Харківський національний медичний університет.

Мінухін Дмитро Валерійович - кандидат медичних наук, доцент кафедри хірургії № 1, Харківський національний медичний університет.

Свтушенко Денис Олександрович - доктор медичних наук, доцент кафедри хірургії № 1, Харківський національний медичний університет. 